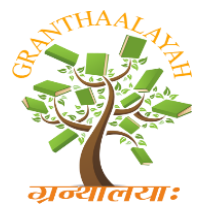

INTERNATIONAL JOURNAL OF RESEARCH GRANTHAALAYAH A knowledge Repository

Social

\title{
GENDER DIFFERENCE IN MORAL JUDGMENT AMONG SECONDARY LEVEL STUDENTS
}

\author{
Dr. Pratik Upadhyaya *1 \\ ${ }^{* 1}$ Assistant Professor, Department of Education, Mahatma Gandhi Antarrashtriya Hindi \\ Vishwavidyalaya, Wardha, INDIA
}

\begin{abstract}
The present study is an attempt to investigate gender difference in moral judgment among secondary level students. The sample for the study consisted of 120 class IX students of Allahabad city. Moral Judgment Questionnaire' prepared by S.K.Pal and K.S.Misra has been used as a tool for the study. The findings of the study revealed that female students had high moral judgment as compared to their male counterparts.
\end{abstract}

Keywords:

moral judgment, gender difference, students.

Cite This Article: Dr. Pratik Upadhyaya, "GENDER DIFFERENCE IN MORAL JUDGMENT AMONG SECONDARY LEVEL STUDENTS" International Journal of Research - Granthaalayah, Vol. 3, No. 11(2015): 17-20. DOI: 10.29121/granthaalayah.v3.i11.2015.2910.

\section{INTRODUCTION}

In the midst of tremendous growth of science, technology and cult of materialism our natural human and spiritual values have been eroded. In order to keep pace with the ever growing knowledge, students are required to have knowledge of science and technology but along with this another basic thing required to be successful in life is ethical moral values, moral attitude and moral judgment for the promotion of personality and self-esteem. Honesty, altruism, truthfulness, endurance, selflessness, kindness and responsibility are essential for a sound mind and a healthy heart. Moral judgment are evaluations or opinions formed as to whether some action or inaction, intention, motive, character trait, or a person as a whole is good or bad as measured against some standard of good. Moral judgment involves a cognitive capacity to define situations in terms of rights and duties. It requires moral insight, knowledge of standards and the ability to judge situations as right or wrong. Moral judgment is the main cognitive factor in moral consciousness. It involves intuition of moral standard by reason and comparison of a voluntary action with it. It also involves evaluation of voluntary action of it as right and wrong. The emotional factors include the moral sentiments and moral judgments are followed by moral sentiments and not vice versa. Moral obligation is the main conative factor of moral consciousness and moral judgment involves moral obligation or the sense of duty or oughtness. It involves the moral impulse to do the right 
action. According to Prehn et al. (2008), emotional and cognitive components play an important role in moral judgment. Moral judgment depends upon moral development. Piaget (1932) believed that there is an orderly and logical pattern in the development of children's moral judgment. According to Kohlberg, there are three levels of morality. At the pre-conventional level, the child's moral judgments are based on external criteria, as whether the person is punished or not. The standards of right and wrong are absolute and laid down by authority. At the conventional level, the child's judgments are based on the norms and expectations of the group (family, society, and nation). The child recognizes the arbitrariness of social and legal conventions at the postconventional level. Moral judgment is a by-product of the child's general and social environment. Psychological research on moral judgment has long been dominated by a developmental approach investigating the maturation of moral orientations and principles and emphasized the role of conscious and rational reasoning processes (Kohlberg, 1969). Conversely, more recent models emphasize the role of unconscious and intuitive processes in moral judgment (Blair, 1995; Haidt, 2001, 2007; Hauser, 2006; Hauser et al., 2007; Mikhail, 2007). The moral sense is among the most complex aspects of the human mind. Despite substantial evidence confirming gender-related neurobiological and behavioral differences, and psychological research suggesting gender specificities in moral development, whether these differences arise from cultural effects or are innate remains unclear. Fumagalli et al. (2010) found no differences between the two genders in utilitarian responses to non-moral dilemmas and to impersonal moral dilemmas, men gave significantly more utilitarian answers to personal moral (PM) dilemmas (i.e., those courses of action whose endorsement involves highly emotional decisions). Cultural factors such as education and religion had no effect on performance in the moral judgment task. These findings suggest that the cognitive-emotional processes involved in evaluating PM dilemmas differ in men and in women. The present study has been undertaken to study the impact of gender on moral judgment.

\section{OBJECTIVE}

The objective of the study was-

- To compare moral judgment of male and female students.

\section{HYPOTHESIS}

To achieve the above objective the following hypothesis has been formulated and tested-

- There is no significant difference in the moral judgment of male and female students.

\section{METHODOLOGY}

The sample for the study consisted of 60 male and 60 female students studying in class IX in U.P. Board affiliated schools of Allahabad city. 'Moral Judgment Questionnaire' prepared by S.K.Pal and K.S.Misra has been used for measuring moral judgment of students. 't-ratio' has been calculated for the analysis of data. 


\section{RESULT AND DISCUSSION}

Table 1: Mean, S.D. and t-ratio showing the difference in moral judgment of male and female students

\begin{tabular}{|l|l|l|l|l|}
\hline Groups & N & Mean & S.D & t-ratio \\
\hline Male & 60 & 39.5 & 7.6 & $2.34^{*}$ \\
\cline { 1 - 4 } Female & 60 & 42.33 & 5.48 & \\
& & & & \\
\hline
\end{tabular}

* Significant at .05 level

Observation of table 1 shows that the value of t-ratio $(=2.34)$ is significant at .05 level. So, the null hypothesis stands rejected. The results indicate that the mean score of female students $(=42.33)$ was higher than the mean score of male students (39.5) on moral judgment. In other words, it can be said that that, as compared to male students, female students have high moral judgment. The present finding is in accordance with the findings of Larden et.al. (2006) and Pal and Mishra (1992). They found that girls excelled boys in moral judgment. This may be due to the reason that moral judgment is influenced by one's environmental experiences. Females might have ever lasting influence of lesson taught by their parents' teachers, home environment, school and community in comparison to boys. Females are more mature, empathic and have less cognitive distortions (Larden et. al., 2006). Females are better able to judge situations as right or wrong since they have moral insight. However, contrary findings are of Mishra (995), and Padhan and Thakkar (1994). The former found that moral judgment is independent of sex and the latter found that no significant sex difference existed in development of moral judgment.

Women as mothers and teachers play a vital role in the upbringing of children by handing over the baton on 'sanskar', values, moral ethics and spiritual values from one generation to another. So, it can be hoped that the present female adolescent students' showing high moral judgment will remove the dark shadows of dishonesty, selfishness, cruelty and immorality that are enveloping the modern generation. This will help in developing a healthy society.

\section{REFERENCES}

[1] Blair, R. J. R. (1995). A cognitive developmental-approach to morality - investigating the psychopath. Cognition, 57, 1-29.

[2] Fumagalli, M. et al. (2010). Gender related differences in moral judgments. Cognitive Process, 11 (3), 219-226.

[3] Haidt, J. (2007). The new synthesis in moral psychology. Science, 316, 998-1002.

[4] Haidt, J. (2001). The emotional dog and its rational tail: a social intuitionist approach to moral judgment. Psychological Reviews, 108, 814-834.

[5] Hauser M., Cushman F., Young L., Jin, R. K. X., Mikhail, J. (2007). A dissociation between moral judgments and justications. Mind \& Language, 22,1-21.

[6] Hauser, M. D. (2006). The liver and the moral organ. Social Cognitive and Affective Neuroscience, 1,214-20.

[7] Kohlberg, L. (1969). In D. A. Goslin (Ed.) Handbook of Socialization Theory and Research, Stage and Sequence: The Cognitive-Developmental Approach to Socialization. Chicago: Ran McNally, pp 347-480. 
[8] Larden et. al. (2006). Moral judgment, cognitive distortions and empathy in

[9] Mikhail, J. (2007). Universal moral grammar: theory, evidence and the future. Trends in Cognitive Sciences, 11, 143-52.

[10] Mishra, K.P. (1995). Comparitive study of cognitive development model with motivation, social behaviour patterns and moral judgment of adolescents from deprived ecologies. Researches and Studies, 43,1-7.

[11] Padhan, G.C. and Thakar, A. (1994). Moral judgment among different types of school students in relation to intelligence. Indian Educational Abstracts.

[12] Pal, S.K. and Misra, K.S. (1992). A study of cognitive process, academic

[13] Prehn, K. (2008). Individual differences in moral judgment competence influence neural correlates of socio-normative judgment. . Social Cognitive and Affective Neuroscience, 3 (1), 33-46. Traditional approach in terms of moral development and value clarification in secondary school students. Indian Educational Abstracts.

[14] www3.sympatico.ca/saburns 